\author{
УДК 325.2:331.1 \\ JEL F22, J60 \\ DOI https://doi.org/10.17721/tppe.2019.38.7
}

\author{
Iryna Sakharuk, Associate Professor \\ Alina Magomedova, Associate Professor \\ Taras Shevchenko National University of Kyiv
}

\title{
DEFINITION AND FACTORS CONTRIBUTING TO THE DEVELOPMENT OF WORKFORCE POTENTIAL IN UKRAINE
}

The paper deals with the definition of workforce potential. Given the complexity of the phenomenon, the category of workforce potential has been studied predominantly from the economic and legal perspectives. The paper suggests that the key factors that affect the development of workforce potential of Ukraine include: social and economic protection of workers, including unemployment rate, remuneration level, work-related injuries, shadow employment; education and training at higher and vocational levels, the match between the graduates' knowledge and skills and the employer's requirements and expectations; demographics, including birth and mortality rates, and life expectancy; level of external migration for employment and educational purpose; public health and health care.

Keywords: potential, workforce potential, labour resources, migration.

Problem statement. Recent dynamics of migration processes in Ukraine has been the subject of research by experts in various fields. The situation with external migration is raising most concerns since the number of persons wishing to leave the country is steadily increasing every year. This significantly affects the economic, demographic, social and other aspects of country development. In this context, the problem of retaining workforce and developing is potential in Ukraine has become pressing and calls for a thorough analysis.

We agree with M.V. Kravchenko, that the workforce potential, i.e. knowledge, level of education, competences, skills and working experience, of any country accumulates over generations and it is the workforce productivity that determines the pace of social development of a state[1]. At the same time, the Concept of the Nation-Wide Targeted Social Program for Preserving and Developing the Workforce Potential of Ukraine till 2017 as of July 22, 2009, emphasised that there is a problem of discrepancy between the existing workforce potential and the current requirements of the economic and social development of the country and this compels the state to take systematic measures in order to sustain, upgrade and develop workforce potential under conditions of financial crisis and at the stabilisation stage of the economy [2]. The Decree of the President of Ukraine on Main Directions of the Development of Workforce Potential till 2010, dated August 03, 1999, outlines the need to develop an evidence-based vision of workforce potential that would become a foundation for practical actions in this area [3, c.1608]. According to the ruling of the National Tripartite Social and Economic Council as of 05.04.2018, the measures for preserving and developing workforce potential and fuelling 
the economy with highly-qualified professionals are among the priorities of the Council in the period of 2018-2020 [4]. Thus, the relevance and importance of the issue of development of the workforce potential in Ukraine is recognized not only by the government institutions, but also by all the stakeholders of social partnership including employers and employees.

Review of recent publications. The category of 'workforce potential' is relatively new for the local economic literature and it first appeared in publications in the 1980s [5, c.20]. The most comprehensive studies in this field have been carried out by Z.P. Barannik, L.V. Halaz, T.V. Davydiuk, V.V. Kozar, M.P.Martianova, S.R. Paseiieka, V.M. Ruban, O.A. Turetsky. M.V. Kravchenko conducted a detailed study into the formation of labour potential from the standpoint of public administration. V.M. Andriyiiv, M.I. Inshyn, V.L. Kostyuk, E.V. Krasnov, O.M. Yaroshenko explored the issue of developing the workforce potential from the legal perspective, while S.V. Venediktov, L.P. Garashchenko, H.O. Spitsyna, Y.V. Chyzhmar, and V.I. Shcherbin studied it within the international labour standards.

Statement of research gap. Currently, the category of workforce potential has been researched mainly by scholars in the field of economics, therefore, we reckon that when analysing the issues of workforce retention and development of its potential, it is essential to study the nature and key features of this category from a legal standpoint.

The purpose of the paper is to explore the theory and key features of workforce potential from different research standpoints.

Research methodology. The theoretical and methodological basis of this paper is a set of general and specific research methods, principles, rules and techniques justified by the topic of research and its purpose. We used methods of analysis and synthesis, as well as historical method to define the categories of potential and workforce potential; a comparison method was used to study the shared and distinctive features of the two categories, namely workforce potential and labour resources; logical, systematic and structural analyses were used to identify major research areas of the workforce potential category; and the generalisation method was used when formulating the authors' definition of workforce potential.

Findings of research. Research literature features several approaches to the interpretation of workforce potential. However, since, as noted above, workforce potential is considered mainly as an economic category, numerous definitions have a purely economic focus. Moreover, among more comprehensive definitions that could be applied in law, there is no single approach shared by scholars. Yet, there are three main standpoints, according to which the workforce potential is regarded as:

1. a category characterised by a set of qualitative indicators;

2. a category characterised by a set of quantitative indicators;

3. a complex social and economic category.

The proponents of the first approach consider workforce potential, primarily, as an availability of certain capacities and their combinations. In our opinion, this standpoint, is justified by the interpretation of the concept of potential as one of the elements of workforce potential. 
Hence, the term potential from the etymological point of view is considered as: a) a total of all available means, capacities, productive forces, etc., which can be used in any industry, area, or field; b) a stock of something, a reserve; or c) latent capacities, forces for any activity that may manifest themselves under certain conditions [6]. A.S. Holovko interprets the concept of potential as an opportunity to realise the existing prerequisites, a set of means and capacities, as well as internal capabilities [7, c.15].

With respect to a particular subject, the potential may refer to existence of explicit or implicit abilities, which being realised, under certain conditions, lead to an increase in the effectiveness of that subject. It can be argued that potential encompasses three aspects of a relationship - the consequences of the past, the existing state of the present, and the implication for the future. Thus, it incorporates the accumulated properties utilised in the present, and also their development and acquisition of new capacities in the future [8, c.247].

Therefore, the category of potential is synonymous to the category of capacity. Accordingly, most generally, workforce potential is the availability of capacities or, in this interpretation, opportunities for an employee, enterprise, society, or a state (depending on the level at which it is considered) and the ability to utilise them (in order to generate income, to improve the welfare of society, to foster the states' economic development).

Among various definitions of "workforce potential" based on qualitative characteristics and using the capacity category, we consider the following ones as those that make most sense:

- workforce potential as a wide range of capacities of the working population, characterised by additional labour reserves, stemming from various human qualities and the results of peoples' collective activity [9, c.43];

- workforce potential as existing and potential capacities for labour, taking into account physical, professional, creative characteristics necessary for fulfilling certain functions and meeting certain needs [10, c.113];

- workforce potential as employment capacity of economically active population, with regard to their quantitative and qualitative characteristics, realised in the form of socially useful work of the proper quality and quantity meeting the needs at the macro level.

Some scholars, when they use the concept of capacity to interpret workforce potential, interpret it differently. For example, V.M. Ruban and M.V. Pustovit define workforce potential as a capacity of making the most efficient use of economically active population through a system of purposeful influence on their quantitative and qualitative parameters, both in the considered period and in the future [11, c.82]. It is difficult to agree with this definition, because, in our opinion, the authors focus not on the nature of workforce potential as a category, but on the state policy on its formation and development.

Overall, based on the approach analysed, the workforce potential of Ukraine may be defined as both existing and prospective capacity of the country's economically active population to realise the right to work and meet their personal and societal needs.

To characterise the category of working potential, it is important to bear in mind that the concept of potential includes the consequences of the past, the existing state in the present and the implications for the future. Accordingly, the workforce potential of Ukraine is 
determined based on what shaped it in the past, as well as the current state of the economy, how developed the labour legislation is and how the execution of labour rights is guaranteed, the demographic situation, etc. Only a purposeful influence on these factors together with balanced socio-economic policy will lead to the development of workforce potential in the future.

The second approach deals with considering workforce potential as a category characterised by a set of quantitative indicators. Scholars who interpret workforce potential by its quantitative traits generally relate workforce potential to the number of economically active or working population.

For instance, Y.Y. Kolos treats the workforce potential of society as the whole population of a country, with the exception of incapacitated persons who, even under certain conditions of treatment and rehabilitation, are unable to bring material, physical or moral value to the members of the society [12, c.226]. It seems that this definition contains a contradiction, since the author, on the one hand, refers to the workforce potential of the whole population, not only the working one, and on the other, the defining feature of workforce potential is its socio-economic benefit.

A.S. Holovko views workforce potential as:

- the amount of labour resources that can be obtained by attracting unused manpower;

- all working-age population with regards to their intellectual development, abilities, knowledge, skills, experience, beliefs, customs, traditions, values and level of patriotism;

- a system consisting of several gender and age-based groups of workers having different potentials, qualitatively characterised by educational and qualification level and working experience in chosen specialty [7, c.14].

Essentially, Holovko suggests considering workforce potential primarily as a quantitative category, as a working age population, followed by characterisation of their qualitative capabilities.

S.R. Pasiieka using the term labour-resource approach views labour potential as a set of available labour resources possessed by a society at a certain stage of development $[13, c .127]$. The kinds of resources the scholar is referring to are not specified, however, based on the name of the approach to the interpretation of labour potential, it seems that it deals with workforce resources.

The quantitative approach is used in the definition of workforce potential suggested by V.M. Ruban and V.M. Pustovit; according to the authors, workforce potential is a totality of various qualities of people that determine their ability to work, or a potential amount and quality of labour that a society has at its current stage of development of science and technology $[11, c .79]$. This definition suggests that the scholars focus on the entirety of the population's qualities, which predetermine their capacity to carry out socially useful activities, rather than the number of economically active population.

In fact, the approach to interpreting labour potential in terms of quantitative characteristics also applies at the regulatory level. Thus, in accordance with the Decree of the President of Ukraine Decree of the President of Ukraine on the Main Directions of the Development of Workforce Potential till 2010, workforce potential is the aggregate number of working-age citizens who possess certain characteristics (health status, 
psychophysiological characteristics, educational, professional and intellectual levels, socio-ethnic mentality), who are capable of and intend to pursue employment [3].

This definition implies a somehow narrow approach, even in terms of quantitative characteristics alone, since it does not take into account the following factors: a) the development of workforce potential involves persons who have not yet reached the working age and, in general, the future generations; b) persons who have reached retirement age may continue to work, and therefore have to be accounted for in the category of workforce potential, c) persons of working age who work or intend work abroad or do not plan to work at all shall not be included in the category of workforce potential of Ukraine.

At the same time, as emphasized in scholarly literature, the definition of workforce potential currently used at the state level in Ukraine does not regard it as a systemic and continuously evolving phenomenon [12, c.227]. Moreover, the meaning of the country's workforce potential enshrined in the law is inconsistent with the definition of potential since it ignores prospective labour capacities. In essence, such an interpretation is a synonymous workforce that cannot be correct. Essentially, such interpretation reduces workforce potential to labour resources, which is not correct. [14, c.247].

Indeed, the proponents of the approach to determining workforce potential through the totality of the economically active population of the country merely equate workforce potential to labour resources. However, these categories, in our opinion, should be distinguished, and such approach is more common among scholars.

Thus, according to A.S. Holovko, workforce potential is characterised not only by the total number of individuals, but also includes a set of different qualities that determine their working capacity. The development of workforce potential takes place according to the following sequence: 'population - labour resources - workforce potential' [7, c.16].

L.V. Halaz points out that along with the concept of "labour resources", which has a clear quantitative definition, the concept of "workforce potential" is interpreted with emphasis towards the development of its qualitative characteristics. [5, c.20].

As V.M. Ruban and M.V. Pustovit suggest, labour resources refer to the able-bodied part of the population that has the physical and intellectual capacity to produce material goods and provide services. Unlike labour resources, workforce potential reflects not only the total number of those who are able to work, but also their educational and qualification characteristics, as well as the duration of their engagement in socially-beneficial work under appropriate conditions [11, c.80]. We agree with the conclusion of scholars that workforce potential is defined as labour resources in a qualitative dimension and represents an integral characteristic of the quantity, quality and measure of the aggregate people's working capacity [11, c.80].

Therefore, the concept of workforce potential is broader than one of labour resources since it embraces not only the population of economically active (or able-bodied) population of the country, but also its qualitative characteristics (education, qualification, health status, etc.) that determine the capacity to effectively exercise their right to work. Additionally, the category of labour resources covers only the situation in the country at the current period of time, while workforce potential includes labour resources of the future, 
i.e. allows to predict the amount of labour resources of the country over a certain period of time, taking into account the demographic and economic situation, the status of employment rights, development of education, etc.

Hence, a comprehensive approach is needed to define the category of workforce potential, which, as rightly note M.P. Martianova and Y.S. Yatsun, represents a complex socio-economic category, characterized by a combination of quantitative and qualitative features. [10, c.111].

In that regard, T.V. Bilorus understands workforce potential as "a complex combination of the nation's nations ..., the qualitative characteristics of the able-bodied population with appropriate professional training ... and quantitative characteristics" [15].

According to O.A. Turetsky, workforce potential as a socio-economic category is intended to include the cumulative evaluation of physical and intellectual characteristics of an individual as well as their totality within a single whole (e.g. society, country, region, etc.), which, ultimately, determine their potential for a particular working activity and for professional development. Workforce potential, therefore, includes, on the one hand, people with certain capacities to work who realise them under certain conditions, and - on the other hand - the duration of working time or working period when the realisation of these capacities may take place [16, c.29].

O.I. Simchera views workforce potential as a dynamic integral characteristic of the abilities and capabilities of the population, both existing and prospective, determined in the form of resources and reserves of living labour together with their quantitative and qualitative characteristics, which are realized in socially useful work under the conditions of a certain stage of development of productive forces and production relations and ensure the accomplishment of the set targets [17, c.245].

We agree with N.V. Hladchak, who, in addition to human resources, their working capacities (existing and prospective), includes the environment where working activity takes place or may take place, as an integral part of the country's workforce potential [18, c.83]. These also include the level of compliance with the law in general and with the labour code, in particular, as we as the economic and demographic situation, etc..

Summarizing the above-mentioned standpoints from the point of view of a comprehensive approach, we believe that the workforce potential of Ukraine can be defined as a socio-economic category, characterised by a combination of population, its qualitative characteristics (education, qualifications, etc.), existing and potential opportunities to exercise the right to work aimed at satisfying their personal and societal needs. That said, we believe that the definition of workforce potential through the categories of "able-bodied population" or "economically active population" significantly narrows its meaning and fails to take into account the prospective working capacity (specifically, younger population who have not reached the working age yet).

To ensure the thoroughness of the analysis of the category workforce potential of the state, it is essential to take into account the principles of hierarchy and complexity. According to the principle of hierarchy, as states V.V. Kozar, the workforce potential of a society integrates lower levels of workforce potential: that of an individual worker, firm, type of economic activity, or region. The principle of complexity entails the study of the structure 
of workforce potential by singling out and analysing individual components of the potential (natural and demographic, educational, professional, social, and motivational) and the ways they interact with each other [19, c.103].

In doing so, the components of the country's (or region's) workforce potential should be divided into quantitative and qualitative ones. The former refer to the size of population and its density, demographics, migration, employment and unemployment rates. The qualitative component should include indicators of health status, educational and professional levels, competency and intellectual level of labour resources, etc. [8, c.250].

Accordingly, in order to maintain and develop Ukraine's workforce potential, it is important to analyse all of these indicators and identifying the measures that me lead to their improvement. At the same time, as mentioned above, the environment where the workforce potential is shaped also plays a significant role. That is why it is of paramount importance to pursue a consistent public policy aimed at creating favourable conditions for the development of workforce potential.

Currently, Ukraine has to public policy with regard to protection and development of the country's workforce potential. The Concept of the Nation-Wide Targeted Social Program for Preserving and Developing the Workforce Potential of Ukraine till 2017 was adopted on July 22, 2009. [2]. It is no longer effective; moreover, the corresponding Programme for its implementation had never been developed and approved, although in accordance with the Concept, its implementation had been planned for 2010-2017.

Development and adoption of a comprehensive program for upholding and developing the workforce potential of Ukraine and its implementation "on the basis of coordinated efforts of all the stakeholders, including education, employment and labour services, migration agencies, etc." is to be on the top of the state's social agenda, according to Y.Y. Kolos [12, c.225].

On top of that, practical efforts aimed at the development of workforce potential will have a positive effect on the economic situation of the country. We agree with A.V. Sokolov that the efficiency of realisation of the workforce potential has a direct "impact" on the standard of living, because the higher the labour efficiency is, the greater is their contribution to the national wealth and their personal income, and, consequently, the higher is the country's standard of living [20, c.12]. Workforce potential is always a driving force behind the economy of the state and the welfare of society [1].

To develop an effective strategy to uphold Ukraine's workforce potential, it is fundamental to analyse the factors that influence its development. Implementation of measures to achieve a positive impact on these factors shall determine the priorities of the state's socio-economic policy for protection and development of workforce potential.

As O.A. Turetsky rightfully notes, the general conditions and prerequisites for the formation of workforce potential should take into account:

- general demographics of workforce potential based on the existing trends in birth rate, mortality, life expectancy, gender and age structure of the population, its aging, dynamics of depopulation, scale and nature of migration processes; 
- system of education and vocational training, including the systems of pre-school education, secondary school and tertiary education, including vocational training at different levels;

- employment rate of the population, structure of unemployed population including hidden unemployment, reduction or increase in the share knowledge-based jobs in the structure of the working potential;

- real incomes and living standards, real wages, share of pay and remuneration in the structure of general incomes of the population;

- health status of all segments of the population, especially children and adolescents, provision of preventive measures, treatment and well-being of the population, taking into account the level and nature of homelessness and begging [16, c.30].

According to S.V. Sember, the factors that influence qualitative and quantitative characteristics of the formation of workforce potential include: a) economic factors related to the development of regional employment programs, support of various forms of employment, remuneration, control over financial sanctions, etc.; b) administrative factors, including regulations initiated by municipal authorities and executive bodies and aimed to strengthen employability, setting labour quotas for different segments of working population; c) social factors related to opportunities of gaining professional qualifications and, specifically, introduction of social protection mechanisms for the working-age population, creating social partnership system, etc.; and c) psychological factors, i.e. the development of special adaptive measures that can help cushion the process of adaptation of the population to the new conditions of market environment, etc. [21, c.8].

0 . Novikova in her analysis of risk factors contributing to the deterioration of workforce potential in Ukraine, mentions the following: - unfavourable socio-economic conditions for the formation of high quality workforce potential prior to reaching working age; - lack of state's efforts to maintain and develop workforce potential; - legislative imperfections in social and labour spheres, incompleteness and inconsistency of existing legal provisions with economic, migration, tax, financial, budgetary, and civil laws; - existing shadow employer-employee relations in the labour sphere; - lack of corporate efforts aimed at the development of workforce potential; - significant outflows of economically active population abroad; - a significant number of threats that have a detrimental effect on workers' physical and mental state [22].

Analysing the trends inhibiting the development Ukraine's workforce potential, T. Bilorus singles out the decreased opportunities for acquiring quality education and professional qualifications: the quality of vocational education and training and the existing supply of labour resources do not meet the requirements of the labour market, whereas the education sector is not sufficiently focused on innovative strategies. The author also mentions deteriorated health indicators of the population, as well as the worsening quality of free health care services provided [9, c.43].

According to A.V. Cherep and Y.O. Zubritska, the key factor that determines the formation of workforce potential is education, which includes the quality and accessibility of secondary and vocational education, professional and vocational training and retraining, on-site continuous professional development, etc. [8, c.251]. This factor< according to 
authors, is instrumental to ensuring high quality and capacity of workforce potential at any level, and we agree with their conclusion.

The Decree of the President of Ukraine on Main Directions of the Development of Workforce Potential till 2010, dated August 03, 1999 defined that the purpose of the state policy on the development of workforce potential is to create legal, economic, social and organisational foundations for its production, protection, and development by creating conditions for: 1) improvement of the natural basis for the formation of the workforce; 2) obtaining vocational and higher education, professional training, retraining and advanced training in accordance with societal needs; 3) full productive employment; 4) prevention of mass unemployment; 5) improvement of occupational safety, reducing health and life risks in the workplace; 6) providing social protection of working and non-working population; 7) strengthening the generative, stimulating and regulating functions of pay; 8 ) facilitating the growth of population's real income; 9 ) ensuring protection of human rights and guarantees in the field of social and labour relations [3]. Even though these conditions were formulated back in 1999, they are still relevant, as most of them are related to social and labour relations that have not yet received a proper legal foundation for being reformed in the last 20 years.

Conclusions. The retention and development of workforce potential as a prerequisite for socio-economic progress has become one of the priorities for the states in the 21st century. Workforce potential is a complex category and its definition stems from the environment where it is formed. In this paper, the category of workforce potential is analysed from the standpoint of three main areas, namely, as a category characterised by a set of qualitative indicators; as a category characterised by a set of quantitative indicators; and as a complex socio-economic category.

A significant number of different factors affects the formation, retention, and development of the state's workforce potential. At this, some of the factors have a direct impact, while others - indirect. Moreover, some of the factors, in our opinion, should be classified as main, while others have mostly classifying and supplementing nature.

Prospects for further research include developing the rationale for programmes and strategies aimed at retention and development of workforce potential in Ukraine in order to address the pressing social and economic problems in the country.

\section{Bibliography}

1. Кравченко М.В. Проблеми та перспективи розвитку трудового потенціалу України: регіональний вимір // Державне будівництво. 2007. №1(2). URL: http://nbuv.gov.ua/UJRN/DeBu_2007_1\%282\%29_22 (дата звернення - 29.05.18)

2. Концепція Загальнодержавної цільової соціальної програми збереження і розвитку трудового потенціалу України на період до 2017 року: розпорядження Кабінету Міністрів України від 22.07.2009 № 851-p. URL: https://www.kmu.gov.ua/ua/npas/230430428 (дата звернення 30.05.18)

3. Про основні напрями розвитку трудового потенціалу на період до 2010 року: Указ Президента України від 03.08.1999 №959/99 // Офіційний вісник України. 1999. №31. Ст.1608 
4. Про збереження та розвиток трудового потенціалу України: Рішення Національної тристоронньої соціально-економічної ради від 05.04.2018 №1. URL: http://www.ntser.gov.ua/sessions-materials/25 (дата звернення - 30.05.18)

5. Галаз Л.В. Трудовий потенціал як фрактор економічного зростання // Вісник Національного університету «Львівська політехніка». Проблеми економіки та управління. 2007. №582. С.19-23.

6. Словник української мови. Академічний тлумачний словник (1970-1980) http://sum.in.ua/s/potencial

7. Головко А.С. Теоретико-методичний зміст категорій «трудовий потенціал», «кадровий потенціал» та «трудові ресурси»// Вісник Хмельницького національного університету. 2010. №3 Т.2 C.14-16

8. Череп А.В., Зубрицька Я.О. Основи формування трудового потенціалу в державі, регіоні, на підприємстві // Вісник Запорізького національного університету. Економічні науки. 2011. №1 (9). C.245-254.

9. Білорус Т. Трудовий потенціал України: сучасний стан та перспективи розвитку // Вісник Київського національного університету імені Тараса Шевченка. Економіка. 2012. №137. С.42-45

10. Мартіянова М.П., Яцун Я.С. Дослідження основних підходів до визначення поняття «трудовий потенціал» // Науковий вісник Херсонського державного університету. Серія: Економічні науки. 2014. Випуск 7(3). С.111- 114.

11. Рубан В.М., Пустовіт М.В. Визначення трудового потенціалу в контексті сучасних світових економічних трансформацій // Экономика и управление. 2009. №6. С.78-83.

12. Колос Ю.Ю. Трудовий потенціал України: визначення та розвиток // Наукові праці Кіровоградського національного технічного університету. Економічні науки. 2009. Випуск 15. С.225229.

13. Пасєка С.Р. Соціально-трудовий потенціал як економічна категорія // Чернігівський науковий часопис Чернігівського державного інституту економіки і управління. Сер. 1 : Економіка і управління. 2011. №2(2). С.125-131.

14. Череп А.В., Зубрицька Я.О. Основи формування трудового потенціалу в державі, регіоні, на підприємстві // Вісник Запорізького національного університету. Економічні науки. 2011. №1 (9). C.245-254.

15. Білорус Т.В. Стратегічне управління кадровим потенціалом підприємства: монографія. Ірпінь: НАДПСУ, $2007 . \quad 174 \quad$ c. http://www.econom.univ.kiev.ua/articles/MIID/bilorus/strategichne_upravlinnya_kadrovim_potencialom_ pidpriemstva.pdf (дата звернення - 28.05.18).

16. Турецький О.А. Процес формування трудового потенціалу постіндустріального суспільства // Ринкова економіка: сучасна теорія і практика управління. 2016. Том 15. Вип.1. С.22-35.

17. Сімчера О.І. Наукові підходи до дослідження сутності трудового потенціалу підприємства // Економічний простір. 2013. №75. С.240-249.

18. Гладчак Н.В. Сутність трудового потенціалу: теоретичні основи формування дефініцій // Науковий вісник Ужгородського університету. Серія: Економіка. 2011. Спецвип. 33. Ч.1. С.79-83.

19. Козар В.В. Стратегічні напрямки збереження та розвитку трудового потенціалу. Проблеми і перспективи економіки та управління. 2015. №4(4). С.101-108.

20. Соколов А.В. Трудові ресурси як чинник впливу на стійкий соціально-економічний розвиток // Держава та регіони. Серія: Економіка та підприємництво. 2015. №5(86). С.10-14.

21. Сембер С.В. Використання трудового потенціалу в умовах структурної перебудови економіки : автореф. дис. канд. екон. наук: спец. 08.09 .01 «Демографія, економіка праці, соціальна економіка і політика». Львів, 2000. 19 с.

22. Новікова О. Напрями вдосконалення державного та регіонального управління щодо збереження та розвитку трудового потенціалу України // Україна : аспекти праці. 2005. №2. С.3-12. 


\section{References}

1. Kravchenko M.V. Problemy ta perspektyvy rozvytku trudovoho potentsialu Ukrainy: rehionalnyi $\begin{array}{lllll}\text { vymir } \quad \text { Derzhavne } & \text { budivnytstvo. } 2007 . & \text { №1(2). }\end{array}$ http://nbuv.gov.ua/UJRN/DeBu_2007_1\%282\%29_22 (data zvernennia - 29.05.18)

2. Kontseptsiia Zahalnoderzhavnoi tsilovoi sotsialnoi prohramy zberezhennia i rozvytku trudovoho potentsialu Ukrainy na period do 2017 roku: rozporiadzhennia Kabinetu Ministriv Ukrainy vid 22.07.2009 № 851-r. URL: https://www.kmu.gov.ua/ua/npas/230430428 (data zvernennia - 30.05.18)

3. Pro osnovni napriamy rozvytku trudovoho potentsialu na period do 2010 roku: Ukaz Prezydenta Ukrainy vid 03.08.1999 №959/99 // Ofitsiinyi visnyk Ukrainy. 1999. №31. St.1608

4. Pro zberezhennia ta rozvytok trudovoho potentsialu Ukrainy: Rishennia Natsionalnoi trystoronnoi sotsialno-ekonomichnoi rady vid 05.04.2018 №1. URL: http://www.ntser.gov.ua/sessions-materials/25 (data zvernennia - 30.05.18)

5. Halaz L.V. Trudovyi potentsial yak faktor ekonomichnoho zrostannia // Visnyk Natsionalnoho universytetu «Lvivska politekhnika». Problemy ekonomiky ta upravlinnia. 2007. №582. S.19-23.

6. Slovnyk ukrainskoi movy. Akademichnyi tlumachnyi slovnyk (1970-1980) http://sum.in.ua/s/potencial

7. Holovko A.S. Teoretyko-metodychnyi zmist katehorii «trudovyi potentsial», «kadrovyi potentsial» ta «trudovi resursy»// Visnyk Khmelnytskoho natsionalnoho universytetu. 2010. №3 T.2 S.14-16

8. Cherep A.V., Zubrytska Ya.O. Osnovy formuvannia trudovoho potentsialu v derzhavi, rehioni, na pidpryiemstvi // Visnyk Zaporizkoho natsionalnoho universytetu. Ekonomichni nauky. 2011. №1 (9). S.245-254.

9. Bilorus T. Trudovyi potentsial Ukrainy: suchasnyi stan ta perspektyvy rozvytku // Visnyk Kyivskoho natsionalnoho universytetu imeni Tarasa Shevchenka. Ekonomika. 2012. №137. S.42-45

10. Martiianova M.P., Yatsun Ya.S. Doslidzhennia osnovnykh pidkhodiv do vyznachennia poniattia «trudovyi potentsial» // Naukovyi visnyk Khersonskoho derzhavnoho universytetu. Seriia: Ekonomichni nauky. 2014.

11. Ruban V.M., Pustovit M.V. Vyznachennia trudovoho potentsialu v konteksti suchasnykh svitovykh ekonomichnykh transformatsii // Ekonomyka y upravlenye. 2009. №6. S.78-83.

12. Kolos Yu.Yu. Trudovyi potentsial Ukrainy: vyznachennia ta rozvytok // Naukovi pratsi Kirovohradskoho natsionalnoho tekhnichnoho universytetu. Ekonomichni nauky. 2009. Vypusk 15. S.225229.

13. Pasieka S.R. Sotsialno-trudovyi potentsial yak ekonomichna katehoriia // Chernihivskyi naukovyi chasopys Chernihivskoho derzhavnoho instytutu ekonomiky i upravlinnia. Ser. 1 : Ekonomika i upravlinnia. 2011. №2(2). S.125-131.

14. Cherep A.V., Zubrytska Ya.O. Osnovy formuvannia trudovoho potentsialu v derzhavi, rehioni, na pidpryiemstvi // Visnyk Zaporizkoho natsionalnoho universytetu. Ekonomichni nauky. 2011. №1 (9). S.245-254.

15. Bilorus T.V. Stratehichne upravlinnia kadrovym potentsialom pidpryiemstva: monohrafiia. Irpin: NADPSU, $2007 . \quad 174 \quad$ s. http://www.econom.univ.kiev.ua/articles/MIID/bilorus/strategichne_upravlinnya_kadrovim_potencialom_ pidpriemstva.pdf (data zvernennia - 28.05.18).

16. Turetskyi O.A. Protses formuvannia trudovoho potentsialu postindustrialnoho suspilstva // Rynkova ekonomika: suchasna teoriia i praktyka upravlinnia. 2016. Tom 15. Vyp.1. S.22-35.

17. Simchera O.I. Naukovi pidkhody do doslidzhennia sutnosti trudovoho potentsialu pidpryiemstva // Ekonomichnyi prostir. 2013. №75. S.240-249. 
18. Hladchak N.V. Sutnist trudovoho potentsialu: teoretychni osnovy formuvannia definitsii // Naukovyi visnyk Uzhhorodskoho universytetu. Seriia: Ekonomika. 2011. Spetsvyp. 33. Ch.1. S.79-83

19. Kozar V.V. Stratehichni napriamky zberezhennia ta rozvytku trudovoho potentsialu. Problemy i perspektyvy ekonomiky ta upravlinnia. 2015. №4(4). S.101-108.

20. Sokolov A.V. Trudovi resursy yak chynnyk vplyvu na stiikyi sotsialno-ekonomichnyi rozvytok // Derzhava ta rehiony. Seriia: Ekonomika ta pidpryiemnytstvo. 2015. №5(86). S.10-14.

21. Sember S.V. Vykorystannia trudovoho potentsialu v umovakh strukturnoi perebudovy ekonomiky: avtoref. dys. kand. ekon. nauk: spets. 08.09.01 «Demohrafiia, ekonomika pratsi, sotsialna ekonomika i polityka». Lviv, 2000. $19 \mathrm{~s}$.

22. Novikova O. Napriamy vdoskonalennia derzhavnoho ta rehionalnoho upravlinnia shchodo zberezhennia ta rozvytku trudovoho potentsialu Ukrainy // Ukraina : aspekty pratsi. 2005. №2. S.3-12.

Сахарук И.С., доцент

Магомедова А.М., доцент

КНУ имени Тараса Шевченко

\section{СУЩНОСТЬ И ФАКТОРЫ РАЗВИТИЯ ТРУДОВОГО ПОТЕНЦИАЛА В УКРАИНЕ}

Рассмотрено категорию «трудовой потенциал» $c$ экономической $u$ юридической точек зрения. Систематизированы направления исследования трудового потенциала. Определены и обобщены ключевые фракторы, влияющие на состояние и развитие трудового потенциала в Украине.

Ключевые слова: потенциал, трудовой потенциал, трудовые ресурсы, миграция.

\section{Сахарук І.С., доцент}

Магомедова А.М., доцент

КНУ імені Тараса Шевченка

\section{СУТНІСТЬ ТА ФАКТОРИ РОЗВИТКУ ТРУДОВОГО ПОТЕНЦІАЛУ В УКРАЇНІ}

Розглянуто категорію «трудовий потенціал» з економічної та юридичної точок зору. Систематизовано напрямки дослідження трудового потенціалу. Визначено та узагальнено ключові фрактори, які впливають на стан та розвиток трудового потенціалу в Україні.

Ключові слова: потенціал, трудовий потенціал, трудові ресурси, міграція.

*Scientific research was conducted within the state budget theme No19BF042-01M Social and legal principles for preservation and development of workforce potential in Ukraine. 